\title{
Hepatoprotective Effects of Tribulus terrestris Hydro-Alcholic Extract on Non-Alcoholic Fatty Liver-Induced Rats
}

\author{
Efectos Hepatoprotectores del Extracto Hidro-Alcohólico de Tribulus terrestris \\ en Ratas con Inducción de Hígados Grasos no Alcólicos
}

Fatemeh Almasi ${ }^{1}$; Mozafar Khazaei²; Shima chehrei ${ }^{3}$ \& Ali Ghanbari²

ALMASI, F.; KHAZAEI, M.; CHEHREI, S. \& GHANBARI, A. Hepatoprotective effects of tribulus terrestris hydro-alcholic extract on non-alcoholic fatty liver- induced rats. Int. J. Morphol., 35(1):345-350, 2017.

SUMMARY: Non-alcoholic fatty liver induces many complications to the liver tissue and also serum related parameters. Medicinal plants are the safe therapeutic strategy for the treatment of diseases. In this regards, the present study was conducted to evaluate the effect of Tribulus terrestris (T. terrestris) extract on non-alcoholic fatty liver in rats. In this experimental study, thirty male Wistar rats were divided into five groups $(\mathrm{n}=6)$. Animals in experimental groups were received high fructose diet $(70 \%)(\mathrm{HDF})$ daily alone or in combined with daily intraperitoneal injection of 500, 700 and $1000 \mathrm{mg} / \mathrm{kg}$ extract of $T$. terrestris. Control group of rats was feed with standard chow. The serum levels of biomarkers of liver and serum lipid profiles were assessed, also histopathological examination of liver tissue done. Data were analyzed using One-way ANOVA method followed by Tukey's post-hoc multiple comparison test and $\mathrm{P}<0.05$ was considered statistically significant. There were significant improvements for biomarkers of liver tissue $(\mathrm{P}<0.05)$ and serum lipid profiles $(\mathrm{P}<0.01)$ in the HFD-fed rats that were treated with $T$. terrestris extract compare to HFD-fed group. In addition, accumulation of lipids in hepatocytes was significantly reduced in the HFD-fed + extract administrated groups in comparison to HFD-fed rats (P<0.01). T. terrestris extract has protective effects against non-alcoholic fatty liver by changing biomarkers of liver tissue, serum lipid profiles and histopathological anomalies of liver tissue, to normal range.

KEY WORDS: Cholesterol; NAFLD; Rat; Tribulus Terrestris.

\section{INTRODUCTION}

Non-alcoholic fatty liver is a chronic disease with high incidence of $10 \%-24 \%$ in developing countries. Although the disease may occur without any sign, severe infection of liver with fibrosis or cirrhosis, liver failure, hepatocarcinoma, cardiovascular diseases could be seen in patients (Sherlock \& Dooley, 2002). The risk factors for inducing non-alcoholic fatty liver are Insulin resistance, aging, obesity, genetic factor, misfeeding, intestinal infection and finally consumption of some drugs like methotrexate and glococorticoids (Kotronen \& Yki-Järvinen, 2008).

Two hit theory has been considered as the mechanism involving pathogenesis of non-alcoholic fatty liver disease. According to this theory, triglyceride accumulation is the first hit that is occurring by insulin resistance. The second hit is induction of oxidative stress that activates inflammation pathways, targeting mitochondrial function (Pagano et al., 2002; Vanni et al., 2010).
Pathological changes in non- alcoholic steatohepatitis (NASH) could be identified by micro and macro vesicular steatosis, infection and necrosis (. NASH is associated with obesity, diabetes mellitus, insulin resistance, and hyperlipidemia. Although NASH could be diagnosed by increasing alanine aminotransferase (ALT) and aspartat aminoteransferase (AST), histological evaluation of hepatic biopsies has a remarkable role in this respect Pagano et al.).

Adding fructose to the feeding regime of rodents induces steatohepatitis like human and introduces an available animal model to assess fatty liver. In this regard, fructose brings carbon atoms both for glycerol and acyl parts of triglycerides that plays as a suiTableinducer for De novo lipogenesis and also increases oxidant activity in the liver (Basciano et al., 2005).

${ }^{1}$ Student Research committee, Kermanshah University of Medical Sciences, Kermanshah, Iran.

${ }^{2}$ Fertility and Infertility Research Center, Kermanshah University of Medical Sciences, Kermanshah, Iran.

${ }^{3}$ Department of Biology, Arak Branch, Islamic Azad University, Arak, Iran. 
Recently, consumption of medicinal plants and natural antioxidants has been attracted researchers as a strategy for treatment of fatty liver. This theory is based on the involvement of oxidative stress for development of fatty liver to steatohepatitis stage. Tribulus terrestris (T. terrestris) is a perennial creeping herb that is broadly distributed in Mediterranean and subtropical areas. It has been used since ancient times in traditional folk medicine. Studies show that T. terrestris contains steroids, saponins, flavonoids, alkaloids, unsaturated fatty acids, vitamins, tannins, resins, nitrate potassium, aspartic acid and glutamic acid. This plant has several medical advantages including antimicrobial, antibacterial, antioxidant and antitoxic activities used in the treatment of cardiovascular diseases, diabetes, tumors, articular pains and respiratory diseases and reproductive dysfunctions (Qureshi et al., 2014).

In the case of the effect of T. terrestris on serum lipids, it is been shown that both Tribulus alatus (T. alatus) and $T$. terrestris extracts caused a significant decrease in the levels of glycosylated hemoglobin, total cholesterol, triglycerides and LDL-cholesterol in streptozotocin-induced diabetic rats (ElTantawy \& Hassanin, 2007). Further, administration of $T$. terrestris extract could significantly inhibit the gluconeogenesis and influence glycometabolism on normal mice and also reduces the level of triglyceride and the content of cholesterol in the plasma (Keshtmand et al., 2015). In previous works we showed the efficacy of $T$. terrestris extract on kidney injury induced by cisplatin and also side effects of diabetes on testis, sperm parameters and sexual hormones (Keshtmand et al., 2014; Keshtmand et al., 2015; Raoofi et al., 2015).

According to hypolipidemic and antioxidant effect of T. terrestris, this plant was chosen for examination of beneficial effects on non-alcoholic fatty liver- induced in rats and for these proposes the serum level of related parameters, and histopathological characteristic of the livers were evaluated.

\section{MATERIAL AND METHOD}

Plant extract. T. terrestris was purchased from a traditional medicine center and identified and uthenticated by a botanist. T. terrestris seed ( $300 \mathrm{~g}$ ) was powdered and added to $80 \mathrm{ml}$ of ethanol (70\%) and was left to macerate at dark condition and room temperature for 24 hours. Then, the soaked powder were extracted in 48 hours by percolation method and the obtained extract was concentrated in the vacuum and was dried in the flat surface (Keshtmand et al., 2014; Raoofi et al.). The weight of the obtained extract was $23 \mathrm{~g}$. The extract was dissolved in distilled water and was immediately administered interaperitonealy (I.P) to rats, expressed as $\mathrm{mg} / \mathrm{kg}$ of body weight and injection administered from day one for 5 weeks.

Animals. Thirty male Wistar rats (200-250 g) were kept at a temperature of $22 \pm 2{ }^{\circ} \mathrm{C}$, under controlled environmental conditions, 12-hour light-dark cycles and fed standard pellet chow and water ad libitum. All experiment procedures were conducted according to the principles for the care and use of laboratory animals in research and approved by local ethics committee of our university. All rats were weighed at the start of the experiment and before sacrificing in deep anesthesia with chloroform, the body weight and the weight of liver for each rat were measured.

Experimental procedure. The rats were randomly divided into five groups $(\mathrm{n}=6)$ and consumed for a period of 5 weeks by following descriptions of feedingingredients; standard chow for group I (E1) and high fructose (70 \%) diet for group II- V (E2-E5). The diet regime of E3- E5 groups also included 500, 700 and $1000 \mathrm{mg} / \mathrm{kg}$ extract of T. terrestris on it, respectively (Brunt et al., 1999; Keshtmand et al., 2014; Raoofi et al.).

Biochemical factors evaluation. At the end of the experiment, blood samples were taken from heart and preserved in $37^{\circ} \mathrm{C}$ for 30 minutes and centrifuged $(3000 \mathrm{~g})$ for 15 minutes. The serum was collected and preserved in $-20^{\circ} \mathrm{C}$ until measuring levels of total cholesterol (TC), high density lipoprotein cholesterol (HDL-C), Very low density lipoprotein (VLDL), triglycerides (TG), albumin (Alb) also, serum markers of hepatic damage; alkaline phosphatase (ALP), alanine aminotransferase (ALT), aspartate aminotransferase (AST), bilirubin were measured using commercially available kits (ParsAzmun, Tehran, Iran).

Microscopic studies. A part of each fresh liver tissue was fixed in $10 \%$ formalin, embedded in paraffin and finally cut into 5 $\mathrm{mm}$ sections. From each subject, 10 sections were selected randomly and stained with hematoxylin-eosin and of them, 5 random fields were captured by Motic camera for doubleblinded histological assessment, carried out by two other academic members of anatomical sciences group at Kermanshah university of Medical sciences (Khazaei et al., 2012). The histopathological fatty changes were evaluated using the grading and staging system of Brunt et al., that degreed from 0 to 4 as follows: $0=$ without steatosis, $1=<25 \%$ steatosis, $2=$ approximately $26-50 \%$ steatosis, $3=$ approximately $51-75 \%$ steatosis, $4=>76 \%$ steatosis (Brunt et al.).

Statistical analysis. The data were expressed as means $\pm \mathrm{SE}$ and analyzed by spss 16 software (SPSS Inc, Chicago, Illinois). The data were analyzed using One Way ANOVA test followed by Tukey's post-hoc multiple comparison test. $\mathrm{P}<0.05$ was considered statistically significant. 


\section{RESULTS}

The effects of T. terrestris extract on body and liver weights of non-alcoholic fatty liver induced rats are presented in figure 1. The mean weights of body had significantly increased in high fructose group compared to control $(\mathrm{P}<0.001)$ and extract groups $(\mathrm{P}<0.05)($ Fig $1 \mathrm{~A})$. The mean weight of liver was increased in high fructose group $(\mathrm{P}<0.001)$ but did not show any significant differences in three other ones $(\mathrm{P}>0.05)$ (Fig 1B).

Table I. Effect of T. terrestris hydroalcoholic extract on the hepatic steatosis markers of rats fed high fructose diet. E1: control group, E2: High Fructose, E3: High Fructose + T. terrestris $(500 \mathrm{mg} / \mathrm{kg}$ ), E4: High Fructose + T. terrestris $(700 \mathrm{mg} / \mathrm{kg})$, E5: High Fructose + T. terrestris $(1000 \mathrm{mg} / \mathrm{kg})$.

\begin{tabular}{|c|c|c|c|c|c|c|}
\hline \multirow[t]{2}{*}{ Groups } & \multicolumn{5}{|c|}{ Hepatic steatosis grading } & \multirow[t]{2}{*}{$\mathbf{P}$} \\
\hline & $\mathbf{0}$ & I & II & III & IV & \\
\hline E1 & 6 & 0 & 0 & 0 & 0 & $\mathrm{~d}$ \\
\hline $\mathbf{E 2}$ & 0 & 0 & 0 & 2 & 4 & $\mathrm{~b}$ \\
\hline $\mathbf{E 3}$ & 0 & 1 & 2 & 3 & 0 & ac \\
\hline $\mathbf{E 4}$ & 0 & 4 & 2 & 0 & 0 & $\mathrm{~d}$ \\
\hline E5 & 0 & 3 & 2 & 1 & 0 & ac \\
\hline
\end{tabular}

a: $\mathrm{p}<0.01 ; \mathrm{b}: \mathrm{p}<0.05$ compared with control group.

c: $\mathrm{p}<0.01 ; \mathrm{d}, \mathrm{p}<0.05$ compared with high fructose group.

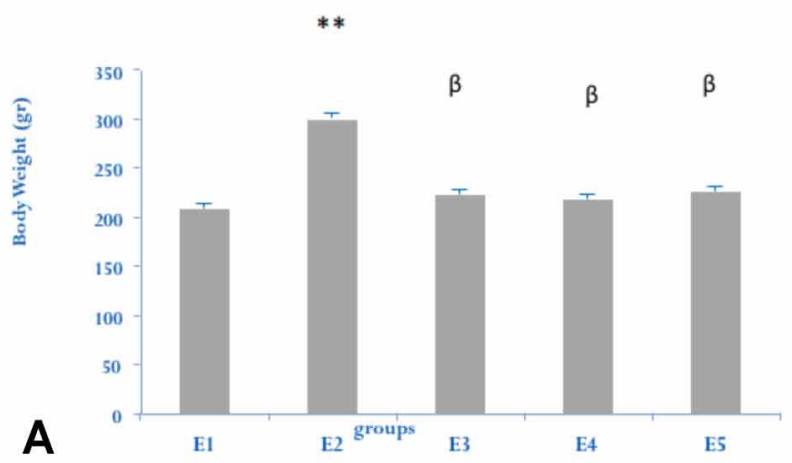

The effects of T. terrestris extract on liver histopathology of non-alcoholic fatty liver induced rats are offered in figure 2. Severe steatosis and congestion in central vein was seen in the high fructose group in compared to control one (Figs. 2A and 2B). A great number of micro and macrovesiculares steatosis were seen in the E3 group (Fig. $2 \mathrm{C}$ ), while the E4 group markedly attenuated the steatosis (Fig. 2D) and microvesicular steatosis was observed in the E5 group (Fig. 2E).

The degrees of steatosis based on the microscopic observations are represented in Table I.

The effects of T. terrestris extract on the biochemical parameters of liver damage are represented in Table II. In comparison with control group, the serum levels of ALT, AST, ALT/ AST, ALP, bilirubin in E2 group were significantly increased but Alb decreased $(\mathrm{P}<0.01)$. In E4 and E5 groups, the levels of ALT, AST, ALT/ AST, ALP, bilirubin and Alb did not show any differences with control (P > 0.05). In E3group, the levels of ALT, AST, ALT/ AST, ALP and bilirubin were increased $(\mathrm{P}<0.05)$ while the levels of Alb significantly decreased $(\mathrm{P}<0.05)$ (Table II).

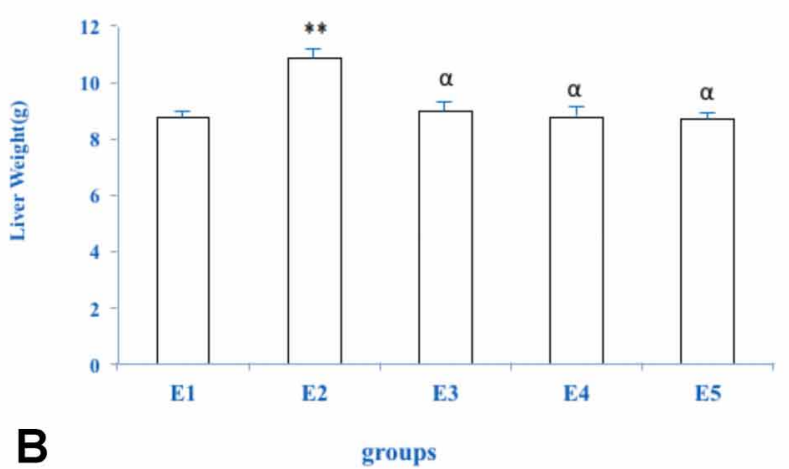

Fig. 1. The effects of T. terrestris extract on body weight (A) and liver weight (B) of non-alcoholic fatty liver induced rats. E1: control group, E2: High Fructose, E3: High Fructose + T. terrestris $(500 \mathrm{mg} / \mathrm{kg})$, E4: High Fructose + T. terrestris (700 mg/kg), E5: High Fructose + T. terrestris $(1000 \mathrm{mg} / \mathrm{kg})$. $* * \mathrm{P}<0.01$ compared with the control group. $\mathrm{a}=\mathrm{P}<0.05$ compared to the High Fructose group, $\mathrm{b}=$ $\mathrm{P}<0.01$ compared with the High Fructose group. The data are presented as mean \pm S.E.M (Standard Error of Mean).

Table II. Effect of T. terrestris hydroalcoholic extract on the biochemical parameters of liver damage of high fructose diet (HFD) fed rats. The data are presented as mean \pm S. E. M

\begin{tabular}{lllllll}
\hline aGroups & ALT U/L & AST U/L & AST/ALT & ALP IU/L & Bilirubin (Mg/dl) & Alb g/dl \\
\hline E1 & $51.23 \pm 1.2^{\mathrm{c}}$ & $50.99 \pm 1.5^{\mathrm{c}}$ & $099^{\mathrm{c}}$ & $184.66 \pm 4.4^{\mathrm{c}}$ & $0.81 \pm 0.06 \mathrm{c}$ & $4.18 \pm 0.4 \mathrm{c}$ \\
E2 & $71.02 \pm 2.3 \mathrm{a}$ & $90.75 \pm 2.7^{\mathrm{a}}$ & $1.27 \mathrm{a}$ & $269 \pm 4.8^{\mathrm{a}}$ & $1.12 \pm 0.05 \mathrm{a}$ & $2.82 \pm 0.5 \mathrm{a}$ \\
E3 & $62.91 \pm 1.3 \mathrm{~b}^{\mathrm{d}}$ & $70.33 \pm 2.6^{\mathrm{bd}}$ & $1.11 \mathrm{~b}^{\mathrm{d}}$ & $215.5 \pm 4.1 \mathrm{~b}^{\mathrm{d}}$ & $1.12 \pm 0.05 \mathrm{~b}^{\mathrm{d}}$ & $3.03 \pm 0.2 \mathrm{~b}^{\mathrm{d}}$ \\
E4 & $61.13 \pm 2.1 \mathrm{c}$ & $60.98 \pm 1.9^{\mathrm{c}}$ & $0.99 \mathrm{c}$ & $211 \pm 5.7^{\mathrm{c}}$ & $0.83 \pm 0.04 \mathrm{c}$ & $3.99 \pm 0.3 \mathrm{c}$ \\
E5 & $59.30 \pm 2.1 \mathrm{c}$ & $58.33 \pm 2.8^{\mathrm{c}}$ & $0.98 \mathrm{c}$ & $188.25 \pm 5.3^{\mathrm{c}}$ & $0.83 \pm 0.04 \mathrm{c}$ & $4.10 \pm 0.5 \mathrm{c}$ \\
\hline
\end{tabular}

E1: control group, E2: High Fructose, E3: High Fructose + T. terrestris $(500 \mathrm{mg} / \mathrm{kg})$, E4: High Fructose + T. terrestris (700 mg/kg), E5: High Fructose + T. terrestris $(1000 \mathrm{mg} / \mathrm{kg})$. a: $\mathrm{p}<0.01 ; \mathrm{b}: \mathrm{p}<0.05$ compared with control group. $\mathrm{c}: \mathrm{p}<0.01 ; \mathrm{d}, \mathrm{p}<0.05$ compared with high fructose group. 

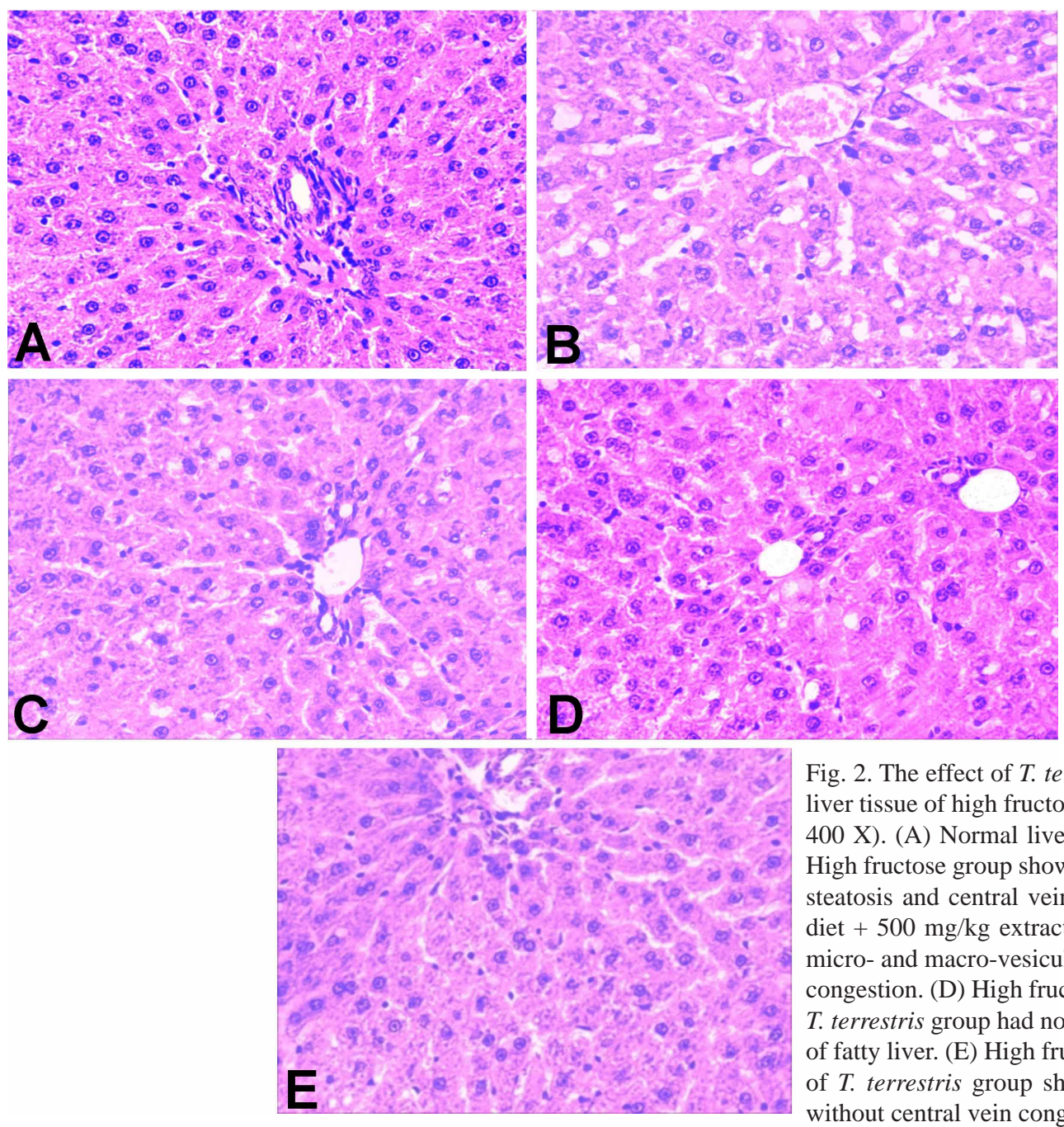

Fig. 2. The effect of T. terrestris hydroalcholic extract on liver tissue of high fructose diet fed rats. (H \& E staining, $400 \mathrm{X}$ ). (A) Normal liver histology (control group). (B) High fructose group showing micro- and macro-vesicular steatosis and central vein congestion. (C) High fructose diet $+500 \mathrm{mg} / \mathrm{kg}$ extract of $T$. terrestris group showing micro- and macro-vesicular steatosis with no central vein congestion. (D) High fructose diet $+700 \mathrm{mg} / \mathrm{kg}$ extract of T. terrestris group had no evidence of histological lesions of fatty liver. (E) High fructose diet $+1000 \mathrm{mg} / \mathrm{kg}$ extract of T. terrestris group showing microvesicular steatosis without central vein congestion.

The effects of T. terrestris extract on lipids profiles are shown in table III. In comparison with control group, the serum levels of TG, total cholesterol, LDL and VLDL were significantly increased in high-fructose diet (E2) $(\mathrm{P}<0.01)$ and High Fructose + T. terrestris $(500 \mathrm{mg} / \mathrm{kg})(\mathrm{E} 3)$ $(\mathrm{P}<0.05)$ groups while, it didn't show remarkable alterations in $\mathrm{E} 4$ and $\mathrm{E} 5$ groups $(\mathrm{P}<0.01)$. Furthermore, serum levels of
TG, total cholesterol, LDL and VLDL were significantly reduced in E3- E5 groups compared to E2 one $(\mathrm{P}<0.05)$ showed attenuation of the extract for these parameters. In contrast, the serum levels of HDL compared to control group, significantly decreased in E2 and E3 groups with $\mathrm{P}<0.01$, $\mathrm{P}<0.05$ respectively, while it didn't changed in E4 and E5 ones $(\mathrm{P}>0.05)$ (Table III).

Table III. Effect of T. terrestris extract on lipid levels in rats fed high-fructose diet (H.F.D).

\begin{tabular}{crrrrr}
\hline VLDL $(\mathrm{mg} / \mathrm{l})$ & HDL $(\mathrm{mg} / \mathrm{l})$ & LDL $(\mathrm{mg} / \mathrm{l})$ & Total cholesterol mg/1 & \multicolumn{1}{c}{ TG $(\mathrm{mg} / \mathrm{l})$} & Groups \\
\hline E1 & $90.26 \pm 4.7 \mathrm{c}$ & $95.41 \pm 3.3^{\mathrm{c}}$ & $24 \pm 1,8^{\mathrm{c}}$ & $51.02 \pm 1.3 \mathrm{c}$ & $25.05 \pm 1.8 \mathrm{c}$ \\
E2 & $211 \pm 3.7 \mathrm{a}$ & $201.66 \pm 2.9^{\mathrm{a}}$ & $50 \pm 2.1^{\mathrm{a}}$ & $41.18 \pm 1.8 \mathrm{a}$ & $73.62 \pm 2.1 \mathrm{a}$ \\
E3 & $120 \pm 5.6^{\mathrm{d}}$ & $111 \pm 2 . \mathrm{b}^{\mathrm{d}}$ & $31.25 \pm 1.8 \mathrm{~b}^{\mathrm{d}}$ & $50.12 \pm 1.6^{\mathrm{bd}}$ & $56.53 \pm 1.9^{\mathrm{bd}}$ \\
E4 & $99 \pm 4.6^{\text {bd }}$ & $99.8 \pm 2 . \mathrm{b}^{\mathrm{d}}$ & $27.12 \pm 2 \mathrm{~b}^{\mathrm{d}}$ & $49.79 \pm 1.4^{\mathrm{bd}}$ & $61.78 \pm 2.4^{\mathrm{bd}}$ \\
E5 & $92 \pm 4.5 .5 \mathrm{c}$ & $94.91 \pm 3.1^{\mathrm{c}}$ & $251 \pm 1.8^{\mathrm{c}}$ & $51.31 \pm 1.7 \mathrm{c}$ & $18.85 \pm 1.1 \mathrm{c}$ \\
\hline
\end{tabular}

E1: control group, E2: High Fructose, E3: High Fructose + T. terrestris (500 mg/kg), E4: High Fructose + T. terrestris (700 mg/kg), E5: High Fructose+ T. terrestris $(1000 \mathrm{mg} / \mathrm{kg})$.Values are presented as mean \pm SEM. a: $\mathrm{p}<0.01 ; \mathrm{b}: \mathrm{p}<0.05$ compared with control group; c: $\mathrm{p}<0.01$, d:p $<0.05$ compared with high fructose group. 


\section{DISCUSSION}

In the present study, the protective effects of $T$. terrestris hydroalcoholic extract against non-alcoholic fatty liver in male rats were evaluated. The results showed that high fructose diet significantly increased the body and liver weight. Fructose in compared to glucose, does not induce production of insulin and secretion of leptin. Insulin and leptin play an important role in the regulation of food intake and energy homeostasis. The declination of plasma insulin and leptin increases blood lipids and weight gain (Lowette et al., 2015).

In addition, fructose is metabolized by the liver into lipids directly. In summary, high fructose diet leads to stimulation of lipogenesis, hepatic insulin resistance, increased food intakes and obesity (Elliott et al., 2002). Moreover, hypercholesterolemia and hypertriglyceridemia are induced by increased secretion of VLDL and decreased clearance of VLDL that justifies the increased plasma level of VLDL in the rats consumed with high fructose diet (Sleder et al., 1980). Thus, the hypertriglycerolemia and hypercholesterolemia in the rats treated with high fructose diet could be explained by the direct and indirect effects of fructose on lipogenesis.

The present study also showed that high fructose consumption induced liver enlargement that should be considered as microsomal enzyme induction leading to increase storage of lipids peroxisome proliferation, and hyperfunction of the liver (Bär et al., 1999). Further, the study demonstrated that $T$. terrestris extract administration decreased the body and liver weight of the rats as well as reduction in the range of steatohepatitis.

The state of liver function could be evaluated by blood assays, describing its functionality (albumin [ALB]), and its link with the billiary tract (ALP) (Agbaje et al., 2009). The improvement of these two biomarkers as long as cholesterol (TC), high density lipoprotein cholesterol (HDL-C), triglycerides (TG) in T. terrestris groups indicated that the extract impaired hepatocellular or secretory functions of the liver in a dose dependent manner.

Two biomarkers of liver damage are AST and ALT. A mild or higher activity of AST indicates liver injury or myocardial infarction and the ratio of AST/ALT may be employed in disease diagnosis (Crook, 2006). An AST/ ALT ratio greater than 1 suggests myocardial infarction while, more than 2 is indicative of alcoholic hepatitis or cirrhosis and ranges from 1.2 to 1.4 , is an indication of the abnormal functioning of the liver (Su et al., 2006).
In the present study, the extract relieved hepatic damage, as revealed by the results of blood chemistry analysis and histopathological assessment; the significant alterations in the indicators of liver damage (ALT, AST, ALP, HDL-C, ALB and triglycerides) and steatosis ratio.

The T. terrestris extract contains flavonoids which are known to have insulin-like properties and also an inhibitory effect on the lipogenase enzyme. Flavonoids improved cell viability and inhibited cellular leakage of hepatocyte AST and ALT (Su et al.). Further, it is been shown that flavonoids can decrease the insulin resistance and insulin requirements in adipose and muscle tissue (Wu et al., 2006). Besides flavonoids, the plant contains alkaloid, glycosides, steroids and saponin that have hypolipidemic properties (Divya et al., 2014).

Alkaloids reduce carbohydrate absorption and metabolism. Thus, this component of the extract could reduce the absorption of fructose and also interrupt the fructose metabolization to lipids (Gosain et al., 2010). Steroids are involved in conversion of cholesterol to VLDL and exertion of cholesterol as the bile. Thus, the increased VLDL as long as decreased total serum level of cholesterol in T. terrestris treated rats could be explained by steroids component of the extract (Fujioka \& Ui, 2001). Saponin is another component of the extract not only regulates lipid metabolism but also improves hypercholesterolemia and hypertriglyceridemia (Yan et al., 1996).

Moreover, polyphenolic and flavonoids compounds of the plant having antioxidant properties are another explanation for antihepatosteatosis of the plant by blocking the second hit of the progression of the disease; oxidative stress (Kumar et al., 2006).

\section{CONCLUSION}

T. terrestris extract administration improves the signs of non-alcoholic fatty liver in rats. The beneficial effects of T. terrestris extract could be seen both in histopathological features and hepatic serum markers of the rats. At histological level, the hepatosteatosis was diminished in T. terrestris extract groups in a dose dependent manner.

ACKNOWLEDGMENTS. We thank the fertility and infertility research center staff for their cooperation. This study was originated from an M.SC thesis and supported by Kermanshah University of Medical Sciences by a grant (No. 93072). 
ALMASI, F; KHAZAEI, M.; CHEHREI, S. \& GHANBARI, A. Efectos hepatoprotectores del extracto hidro-alcohólico de Tribulus terrestris en ratas con inducción de hígados grasos no alcólicos.

RESUMEN: El hígado graso no alcohólico induce muchas complicaciones al tejido hepático y también en ciertos parámetros relacionados con el suero. Las plantas medicinales son la estrategia terapéutica segura para el tratamiento de enfermedades. En este sentido, el presente estudio se realizó para evaluar el efecto del extracto de Tribulus terrestris (T. terrestris) sobre el hígado graso no alcohólico en ratas. En este estudio experimental se dividieron 30 ratas macho Wistar en cinco grupos $(n=6)$. Los animales de los grupos experimentales recibieron dietas altas en fructosa $(70 \%)$ (HDF) al día o en combinación con inyección intraperitoneal diaria de 500, 700 y 1000 $\mathrm{mg} / \mathrm{kg}$ de extracto de T. terrestris. El grupo control de ratas fue alimentado con alimento estándar. Se evaluaron los niveles séricos de biomarcadores hepáticos y perfiles de lípidos séricos, así como un examen histopatológico del tejido hepático. Los datos se analizaron utilizando el método ANOVA de una vía seguido de la prueba de comparación múltiple post-hoc de Tukey y el $\mathrm{P}<0,05$ se consideró estadísticamente significativo. Hubo mejoras significativas en los biomarcadores del tejido hepático $(\mathrm{P}<0,05)$ y en los perfiles de lípidos séricos $(\mathrm{P}<0,01)$ en las ratas alimentadas con HFD que se trataron con extrato de T. terrestris comparado con el grupo alimentado con HFD. Además, la acumulación de lípidos en los hepatocitos se redujo significativamente en los grupos alimentados con HFD + extracto, en comparación con las ratas alimentadas con HFD ( $\mathrm{P}<0,01)$. El extracto de $T$. terrestris tiene efectos protectores sobre el hígado graso no alcohólico, provocando modificaciones en los marcadores biológicos del tejido hepático, los perfiles lipídicos del suero y las anomalías histopatológicas del tejido hepático, hasta un rango normal.

\section{PALABRAS CLAVE: Colesterol; NAFLD; Rata; Tribulus} terrestris.

\section{REFERENCES}

Agbaje, E. O.; Adeneye, A. A.\& Daramola, A. O. Biochemical and toxicological studies of aqueous extract of Syzigium aromaticum (L.) Merr. \& Perry (Myrtaceae) in rodents. Afr. J. Tradit. Complement. Altern. Med., 6(3):241-54, 2009.

Brunt, E. M.; Janney, C. G.; Di Bisceglie, A. M.; Neuschwander-Tetri, B. A. \& Bacon, B. R. Nonalcoholic steatohepatitis: a proposal for grading and staging the histological lesions. Am. J. Gastroenterol., 94(9):2467-74, 1999.

Bär, A. Characteristics and significance of D-tagatose-induced liver enlargement in rats: An interpretative review. Regul. Toxicol. Pharmacol., 29(2 Pt. 2):S83-93, 1999.

Crook, M. A. Clinical Chemistry \& Metabolic Medicine. 7th ed. London, Hodder Arnold, 2006. pp.426.

Divya, M. K.; Sheema, D.; Achuthan, C. R. \& Babu, T. D. Cytotoxic and antitumor effects of Tribulus terrestris L fruit methanolic extract. J. Pharmacogn. Phytochem., 3(2):1-4, 2014.

El-Tantawy, W. H. \& Hassanin, L. A. Hypoglycemic and hypolipidemic effects of alcoholic extract of Tribulus alatus in streptozotocin-induced diabetic rats: a comparative study with T. terrestris (Caltrop). Indian J. Exp. Biol., 45(9):785-90, 2007

Elliott, S. S.; Keim, N. L.; Stern, J. S.; Teff, K. \& Havel, P. J. Fructose, weight gain, and the insulin resistance syndrome. Am. J. Clin. Nutr., 76(5):911-22, 2002.
Fujioka, T. \& Ui, M. Involvement of insulin receptor substrates in epidermal growth factor induced activation of phosphatidylinositol 3-kinase in rat hepatocyte primary culture. Eur. J. Biochem., 268(1):25-34, 2001.

Gosain, S. R.; Ircchiaya, R.; Sharma, P. C.; Thareja, S.; Kalra, A.; Deep, A. \& Bhardwaj, T. R. Hypolipidemic effect of ethanolic extract from the leaves of Hibiscus sabdariffa L. in hyperlipidemic rats. Acta Pol. Pharm., 67(2):179-84, 2010.

Basciano, H.; Federico, L. \& Adeli, K. Fructose, insulin resistance, and metabolic dyslipidemia. Nutr. Metab. (Lond.), 2(1):5, 2005.

Lowette, K.; Roosen, L.; Tack, J. \& Vanden Berghe, P. Effects of high-fructose diets on central appetite signaling and cognitive function. Front. Nutr., $2: 5,2015$.

Keshtmand, Z.; Ghanbari, A.; Khazaei, M. \& Rabzia, A. Protective effect of Tribulus terrestris hydroalcoholic extract against cisplatin-induced apoptosis on testis in mice. Int. J. Morphol., 33(1):279-84, 2015.

Keshtmand, Z.; Oryan, S.; Ghanbari, A. \& Khazaei, M. Protective effect of Tribulus terrestris hydroalcoholic extract against cisplatin-induced cytotoxicity on sperm parameters in male mice. Int. J. Morphol., 32(2):551-7, 2014.

Khazaei, M.; Bayat, P. D.; Ghanbari, A.; Khazaei, S.; Feizian, M.; Khodaei, A. \& Alian, H. A. S. Protective effects of subchronic caffeine administration on cisplatin induced urogenital toxicity in male mice. Indian J. Exp. Biol., 50(9):638-44, 2012

Kotronen, A. \& Yki-Järvinen, H. Fatty liver: a novel component of the metabolic syndrome. Arterioscler. Thromb. Vasc. Biol., 28(1):27-38, 2008.

Kumar, M.; Soni, A. K.; Shukla, S. \& Kumar, A. Chemopreventive potential of Tribulus terrestris against 7,12- dimethylbenz (a) anthracene induced skin papillomagenesis in mice. Asian Pac. J. Cancer Prev., 7(2):289-94, 2006.

Pagano, G.; Pacini, G.; Musso, G.; Gambino, R.; Mecca, F.; Depetris, N.; Cassader, M.; David, E.; Cavallo-Perin, P. \& Rizzetto, M. Nonalcoholic steatohepatitis, insulin resistance, and metabolic syndrome: further evidence for an etiologic association. Hepatology, 35(2):367-72, 2002.

Qureshi, A.; Naughton, D. P. \& Petroczi, A. A systematic review on the herbal extract Tribulus terrestris and the roots of its putative aphrodisiac and performance enhancing effect. J. Diet Suppl., 11(1):64-79, 2014.

Raoofi, A.; Khazaei, M. \& Ghanbari, A. Protective effect of hydroalcoholic extract of Tribulus terrestris on Cisplatin induced renal tissue damage in male mice. Int. J. Prev. Med., 6:11, 2015.

Sherlock, S. \& Dooley, J. Diseases of the Liver and Biliary System. 11th ed. Malden, Blackwell Science, 2002. pp.423-5.

Sleder, J.; Chen, Y. D.; Cully, M. D. \& Reaven, G. M. Hyperinsulinemia in fructose-induced hypertriglyceridemia in the rat. Metabolism, 29(4):3035, 1980.

Su, H. C.; Hung, L. M. \& Chen, J. K. Resveratrol, a red wine antioxidant, possesses an insulin-like effect in streptozotocin-induced diabetic rats. Am. J. Physiol. Endocrinol. Metab., 290(6):E1339-46, 2006.

Wu, Y.; Wang, F.; Zheng, Q.; Lu, L.; Yao, H.; Zhou, C.; Wu, X. \& Zhao, Y. Hepatoprotective effect of total flavonoids from Laggera alata against carbon tetrachloride-induced injury in primary cultured neonatal rat hepatocytes and in rats with hepatic damage. J. Biomed. Sci., 13(4):569$78,2006$.

Yan, W.; Ohtani, K.; Kasai, R. \& Yamasaki, K. Steroidal saponins from fruits of Tribulus terrestris. Phytochemistry, 42(5):1417-22, 1996.

\section{Correspondence author:}

Shima chehrei

Department of Biology

Arak Branch

Islamic Azad University

Arak

IRAN

Received: 01-08-2016

Accepted: 29-12-2016

E-mail: sh-chehreii@iau-arak.ac.ir 